\title{
Promoting health among the elderly: actions in primary health care
}

Abstract

Objective: To identify health promotion actions carried out by professionals in the Family Health Strategy in relation to elderly people. Method: An exploratory study with a qualitative approach was performed in Juazeiro do Norte, Ceará, Brazil, with 19 professionals. A recorded, fully transcribed semi-structured interview was used after authorization by the ethics committee under number 501 675. The discussions were analyzed using Content Analysis, organized into thematic categories. Results: Actions of a collective nature were identified, such as activities in groups, meetings, conversation circles, lectures and guidance in the waiting room. Other directed actions were used, such as guidelines during individual consultations and referral to specialized services. Conclusion: The need for the discussion of health promotion and actions in relation to old age was highlighted, with debate and reflection on this theme required locally, along with the need to build a network of support for the health of the elderly in a shared manner among professionals, managers and the community.

\footnotetext{
Centro Universitário Doutor Leão Sampaio - UNILEÃO, Curso de Graduação em Enfermagem. Juazeiro do Norte, Ceará, Brasil.

2 Universidade Regional do Cariri - URCA, Departamento de Enfermagem. Crato, Ceará, Brasil.

Centro de Hematologia e Hemoterapia do Ceará, Hemovigilância. Crato, Ceará, Brasil.

4 Universidade Estadual do Ceará - UECE, Departamento de Ciências da Saúde. Fortaleza, Ceará, Brasil.

Correspondence

Ana Paula Ribeiro de Castro

anacastro@leaosampaio.edu.br
}

Ana Paula Ribeiro de Castro'

Eglídia Carla Figueirêdo Vidal ${ }^{2}$

Ana Raquel Bezerra Saraiva ${ }^{1}$

Sofia de Moraes Arnaldo

Ana Maria Machado Borges,3

Maria lrismar de Almeida ${ }^{4}$

Keywords: Health of the Elderly. Health Education. Health Promotion. Primary Health Care. Family Health. 


\section{INTRODUCTION}

Population aging can be considered an achievement for Brazil, with improvements in health conditions leading to an increase in life expectancy and a reduction in mortality, especially infant mortality, and fertility until they are at similar levels to developed countries. Little planning has been carried out to deal with this situation, however, and the lack of conditions for active and healthy population aging in most of Brazil affects the quality of life of the elderly ${ }^{1}$.

Such lack of planning represents a major problem as individuals age without the proper care for their new physical and mental condition. This directly affects their well-being and, consequently, their quality of life, as aging with the perception of good health is related to the capacity to engage in self-care activities, express positive emotions and satisfaction with economic and/or social conditions and changes in habits ${ }^{2}$.

According to the Pan American Health Organization (PAHO), human aging can be understood as a sequential, natural, individual, irreversible, universal, cumulative, continuous and non-pathological process, with the gradual and progressive reduction of functional and cognitive capacity resulting from the process of senescence and senility ${ }^{3}$. Understanding this concept and incorporating it into daily professional practice is fundamental to providing care to the elderly population to ensure they perform an active and reflective role in society, with rights and duties, and participate in decision making on their health/ illness process.

Greater longevity and longer life expectancy depend, among other factors, on lifestyle (obesity, sedentarism, smoking, stress), the environment (housing conditions, urbanization), genetic inheritance (related diseases) and the organization of health services (access and adequate care). Longevity is a reality in Brazil, both in relation to the number of elderly people and the increase in life expectancy, resulting in the need for structured public policies that meet the needs of this age group ${ }^{4}$.

Demographic transition is consequently a challenge for health, especially in Brazil, whose status as a developing country means the phenomenon occurs in a scenario of poverty and great social inequalities, in a large territory marked by economic, social and cultural differences. In addition, the health care model in Brazil is still based on curative actions, with the predominance of the medical model and a work process organized by spontaneous demand, and is therefore insufficient to meet the needs of the elderly population ${ }^{5}$.

There is therefore a need for strategies aimed at this population, especially in the health sector ${ }^{6,7}$, in which professionals and managers are prepared to receive and respond to the psychological, physical, socioeconomic and cultural needs of the elderly, based on public policy proposals for an active and healthy aging, as set out in the guidelines on care, operation and management and related policies incorporated within the Unified Health System (SUS), such as the National Health Policy for the Elderly.

Primary Health Care (PHC) in Brazil demands political, economic and institutional decisionmaking, with significant investment in its expansion and the improvement of health care for individuals in territories covered by Family Health Strategy (FHS) teams. This investment is based on the central concept of health promotion to bring about a transformation in the inter/multidisciplinary work process through networks of integrated health care ${ }^{6}$.

In Brazil, despite successful experiences with the implementation of the $\mathrm{FHS}^{8}$, the disease-centered view persists, especially in relation to the elderly population. This is evidenced by outpatient clinics focused on spontaneous demand, home visits restricted to the treatment of chronic diseases and consultations for the follow-up of hypertension and diabetes, with the biomedical model of health care prevailing. In the municipality studied, strategies aimed at promoting health through the work of multidisciplinary teams, supported by the policies of the Ministry of Health, have not yet been incorporated, especially in relation to the elderly.

Medina et al. ${ }^{9}$ suggest that there is a lack of studies that problematize or evaluate the nature and effectiveness of health promotion actions developed in PHC, specifically in the Family Strategy. Based on these reflections, the aim of the present study was 
to identify the actions of health promotion for the elderly population carried out by FHS professionals in Juazeiro do Norte, Ceará, Brazil.

\section{METHOD}

All ethical and legal precepts on research involving human beings have been respected, in compliance with Resolution $N^{\circ}$ 466/2012. The study was registered on the Brazil Platform and submitted to the Ethics Research Committee of the Universidade Estadual do Ceará (Ceará State University) (UECE), and were approved under approval no 501.675 .

An exploratory study with a qualitative approach was carried out, from the comprehensive perspective of the reality experienced in the daily life of the FHS, which is a potentiator of health promotion for the elderly.

The study was carried out in the FHS of the municipal region of Juazeiro do Norte, located in the Metropolitan Region of Cariri in the south of the state of Ceará, Brazil.

Juazeiro do Norte has an area of $141 \mathrm{~km}^{2}$ and an urbanization rate of $95.3 \%$, with a population of 249,939 inhabitants, of which $14 \%$ are aged 60 years and over. The PHC of this municipal region is organized into six districts, with 64 FHS teams, offering coverage of $86.96 \%, 34$ modality I Oral Health Teams (OHT) (without a Dental Hygiene Technician - DHT) and 530 Community Health Agents $(\mathrm{CHA})^{10}$.

The study was conducted in district $\mathrm{V}$, which has thirteen $\mathrm{FHS}^{11}$ teams, totaling 25 professionals, including doctors, nurses and dentists. The choice for this location was based on the fact that it has the greatest number of people aged 60 years or over in the municipal region.

A total of 19 higher-education qualified professionals (four doctors, nine nurses and six dentists) met the following eligibility criteria: to be a professional with a higher-education qualification and have worked for at least one year in the unit. The exclusion criteria were: professionals with a highereducation level qualification who, even including the time of the application process, had worked in the unit for less than a year or were absent from work for any reason.

Three nurses were subsequently excluded due to temporary absence from work, and three doctors refused to participate in the study.

Data collection was carried out in January and February of 2014 by means of a semi-structured interview script, following the consent of the institution and the participants, given by the signing of a Free and Informed Consent Form (FICF). The interviews were previously scheduled at an agreed date, time and place. They had an average duration of 22 minutes. Questions were raised about work carried out involving actions to promote the health of the elderly. The observations and impressions of the researchers were recorded in a field diary. The discourses were identified with the names of angels for the differentiation of the empirical data.

The data was analyzed using the Content Analysis (CA) approach proposed by Bardin ${ }^{12}$. As the interviews were carried out they were transcribed in full and organized based on the CA phases, through pre-analysis, material exploration, treatment of results, inference and interpretation. The organization of material was carried out via thematic categorization, with the evidence grouped into three categories, namely: collective actions of health promotion: empowerment or imposition of health practices; Waiting room: a space for dialogue to promote health? and Individual consultation as an action for the promotion of health: a reality to be overcome.

The criteria for reports of qualitative studies, present in the COREQ - Consolidated criteria for reporting qualitative research ${ }^{12}$ checklist were considered for the elaboration of this manuscript.

\section{RESULTS}

In summary the collective actions were described, such as group activities, meetings, discussion circles, lectures and waiting room orientations, as well as specific actions such as orientation during individual consultation and referral to specialized services. 


\section{Collective actions of health promotion: empowerment or imposition of health practices?}

Among the collective actions to promote the health of the elderly, health groups, working continuously, and in some teams, sporadically, were mentioned, as can be seen in the following reports:

"We have a group. [...] On Mondays, Wednesdays and Fridays, it existed well before the Family Health Support Nucleus (FHSC), an Elderly Persons Group, which does physical activities and celebrates special occasions, such as Mother's Day, Father's Day, Day for Older Persons, they went to Caldas (the Balneário do Caldas resort in Barbalha, Ceará), [...] Festa Junina Parties, Christmas. [...] We even do walks with them, and we rely on FHSC professionals to provide support and guidance as well". (DINIEL).

"There is a health worker who works with this specific group, she promotes and carries out events and celebrates special occasions, with the support of the team, such as São João, she organized transportation with the city council and took them to Caldas (a resort in the city of Barbalha). [...] It isn't a systematic or formal group, because it isn't fixed, but it is an initiative that we look on positively because the results are positive, from their feedback, there are benefits for the individual, with the elderly saying how it changed their lives, even though the initiatives are unsystematic [...]". (HAMON).

The participation of the Family Health Support Center (FHSC) and the CHA is essential to carry out the actions of the health groups mentioned. Even if be non-systematic, as the second statement explains, the benefits of these experiences are clear, as they involve themes and activities that are important for the maintenance of health, such as walking and accident prevention, and recreational and leisure activities such as celebrations of specific dates, which are important in the regional and national calendar, and visits to public places.

It was not discussed how the evaluations of these moments are performed by the FHS, as the groups were carried out sporadically, unsystematically and without any evaluation instruments. There was also a lack of discussion about the understanding of health/disease, culture, the need to prevent violence (in its various forms), sustainable development, or the culture of peace, among others, leading to a dependence on issues related to the control and treatment of chronic noncommunicable diseases.

\section{Waiting room: a space for dialogue to promote health?}

The health professionals interviewed emphasized the implementation of actions to promote the health of the elderly in the reception areas of the Family Health Units (FHU), which are "Waiting Rooms" where "chat" type group actions are carried out, focusing on a previously decided theme or with an open approach to the dialogue and questions of the target audience, focusing on health education as a strategy to promote health in this physical space.

The speakers described the use of the Waiting Room for actions of health promotion, however, due to the spontaneous demands on the service, also referred to the lack of suitable spaces for the organization of other more elaborate actions. They therefore demonstrate difficulties when carrying out such activities due to the characteristics of the environment, as shown in the following discourse:

"[...] we take advantage of times when the team is doing something (waiting room) and we talk with them". (Anael).

"[...] it often takes place in the waiting room, explaining what Is hypertension, what is diabetes, how to treat them, so we stay in the waiting room". (Leo).

"[...] what we do in the waiting room [...] is about getting attention in a crowded space, which has a lot of people together and they really pay attention!" (Barman).

The spaces of the health units can be considered as places for dialogue in the health education process and thus for the promotion of health. It is, however, possible to reflect on the purpose of these moments in the "waiting room", as what is it that the users are "waiting" for, exactly? Reflection, dialogue, the exchange of knowledge on a subject? How do professionals organize this moment of "waiting" for it to become a place for health education? 
Health education should include the active participation of the community and of the group focused on practical activities. It should provide information on health and health education, which is essential knowledge for improving the individual and collective quality of life of participants in the process.

\section{Individual consultation as an action for the promotion of health: a reality to be overcome}

The breakup of the individual health model is not yet an absolute reality. In the midst of attitudes that seek change, we still perceive resistance and the dominance of curative actions, combining actions of health education to promote the health of the elderly, through orientation in individual consultations with an emphasis on disease and the prevention of complications, as well as referral to specialized services, as can be seen in the following discourses:

"The health promotion that we provide is only guidance and referral! So far, we have offered talks specifically for elderly persons". (Dumah).

"Honestly? No! When they come for appointments, we really try to see what we can do [...]”. (Barman).

"We do, to be honest, as I'm here every day at the clinic to oversee control of blood pressure, diabetes". (Rahmiel).

In this study the conception of actions predominantly based in individual clinical consultation was not limited to doctors, as the other professionals interviewed also described the predominance of individual appointments over the collective experience, as can be verified in the following discourses:

"[...] We still offer orientations in nursing consultations and the patient has access to medical consultations, but no more than this, and in these nursing orientations, [...] they are actions in the general sense, they are not specifically aimed at this group". (Adonai).
"[...] there is a very high demand for treatment of hypertension and diabetes, and as a nurse I end up carrying out the treatment, and dealing with the risks they involve, if they do not get the treatment right, more in this area. [...] I instruct them to obey the medical and nursing guidelines, the question of self-care, but specific to other areas [...]". (Baraquiel).

The participants revealed that, even in an individual manner, the contents covered in clinical consultation are relevant to the health of the individual. The explanation of issues related to disease was notable, especially in relation to Systemic Arterial Hypertension and Diabetes, the most prevalent illnesses among the geriatric population; and the connotation of "obedience", where the subject must follow the instructions of the professional providing care. This translates into a health education based on orders, which is far removed from the dimension of the active participation of users of the health system, which is the basis for the promotion of health.

Some of the reports presented demonstrated the lack of health promotion actions, specifically with and for elderly persons. It should be noted that the interviewees had spent more than five years in the FHS (at the time of the study), suggesting the creation of a bond and knowledge of the local reality, resulting in strategies to tackle health promotion.

“There are no activities where I work". (Amitiel).

"At the moment we aren't doing anything!" (Michael).

"Honestly, no! [...] As a team, no! I have never carried out any health promotion activities. Not even with the FHSC. I have no experience of joint actions, none!". (Nanael).

"Not collectively, no. Very few, I really think we need more". (Rahmiel).

The lack of integrated work damages the health promotion of the elderly, leading to reflections about the need for change in the work process of the FHS, as can be seen in the discourse below. Although some 
professionals accept the need to change this reality, certain impediments related to the work process and management, with overlapping areas of care, explain the difficulties.

"[...] we had some time, some meetings, reviewing our work process and we planned meetings, and to work, to expand a little, not only in the area of education, but also the individual approach, which is most often carried out in consultations, to expand it to other times like meetings in the waiting room, to really carry it out, to form a specific group, but unfortunately it hasn't happened, people are still in ideas stage, we are trying to get together to reorganize and do it". (Kalaziel).

"I don't remember! Nothing was done this year. Dentistry is very focused on childhood, you know? We need to improve, to focus more on all ages, not only children". (Minil).

"No! We focus more on schools. [...] I've never taken part in any action with the elderly! We haven't reached that stage yet!'. (Rafael).

\section{DISCUSSION}

A study showed that support groups, notably "Educational Groups", were more efficient not only for the transmission of pre-established knowledge, but also through the large number of topics addressed, allowing the group to garner knowledge and information and achieve emancipation, meeting the individual and collective needs of the participants. In this study, the work of Support Groups for the elderly was not mentioned as a strategy for the promotion of health for this age group ${ }^{13}$.

Efforts should be made to foster the capacity of independence of participants. One point to consider is leisure activities, as these experiences are important for the participants. Health professionals should encourage the autonomy of the elderly so that they can promote leisure activities for themselves, and not become dependent on the healthcare team that cares for them. Teams should rethink their care practices, whether in the FHS or in other spaces, promoting the interconnection of clinical and social sciences and epidemiology $y^{14}$.
In addition, it is necessary to rethink the normative culture in the practice of health education, where centralized rules and norms are established that require actions to be carried out exactly as oriented, and which are handed down in an authoritarian and vertical manner. "Education" therefore implies a context of responsibility for the user in their health and way of life ${ }^{15}$.

Among the discourses, the FHU waiting room, referred to as a space for health promotion actions, may have several configurations, and can be a corridor or a place to wait for consultations, in which sounds and several dynamic movements occur; it can be the most active part of the FHU, and it is important, in carrying out any activities, to seek to focus attention so that the objective is reached. The waiting room can also be set up in a space reserved for group work and, due to the long wait for an appointment, be a time for reception to take place. It is considered a privileged space for educational groups, where the large number of people of different age groups and health profiles who are anxiously awaiting care allows such groups to be carried out, making waiting times useful and easing potential concerns about the consultation ${ }^{16,17}$.

Nevertheless, the activities developed in the waiting room should go beyond taking advantage of the spontaneous demands of the FHU and orientations about disease which are often delivered in a decontextualized way, so that the individual with diabetes and/or arterial hypertension experiences the process of becoming ill in a singular mode. The work of professionals with users in these spaces should have a problematizing perspective, involving active listening, establishing relationships that go beyond random encounters. At this juncture, it is necessary to establish dialogic relationships, producing meanings, in the encounter between different knowledges ${ }^{18,19}$.

It is considered that health promotion actions anchored in health education should seek to transform reality, whose participants are co-participants, and where dialogue is a way to break the traditional and hegemonic model rooted in disease, opening space for collective empowerment.

Health education is one of the main devices to make health promotion feasible and effective, 
as it strengthens the development of individual and collective responsibility for the prevention of health problems ${ }^{13}$.

Thus, in a study conducted with doctors, it was found that the health promotion actions carried out by such professionals were aimed at a clinical approach, with prevention prescribed from diets and exercises ${ }^{20}$.

Even with practices considered emancipatory and participatory in the ESF, there is evidence of a posture of submission of users who remain in the models of conduct and prescription. In the historical process of care relationships, medicine exercises a power that is concentrated in diagnosis and therapeutic interventions, creating a technicalscientific authority. In this context, users enter the service in a state of dependency and alienation, waiting for answers and solutions ${ }^{21}$.

While eradicating this model, allowing active listening and giving a voice to the user is a challenge in any life cycle, it is especially urgent in the elderly phase, given the needs of this population for the consolidation of strategies to improve quality of life and not just the prolongation of life.

The FHS should therefore aim to reorient health services through intersectoral practices and actions. Barriers to such advances exist, such as the fragmentation of the work process and the fragility of the work of care networks. In spite of the elaborated and effective management documents which result from the recognition of the need to improve care for the elderly, such as the National Policy for the Health of the Elderly, the National Immunization Program, the Statute of the Elderly, the Pact for Health, among others, qualitative and quantitative advances are still required in geriatric and gerontological health in $\mathrm{PHC}^{22,23}$.

In addition, PHC workers are responsible for health promotion actions, breaking the vertical, immediate and disease-centered health care model. Health education is one of the proposals for this dialogue, and it is important to invest in management and in the FHS, so as not to risk of perpetuating an authoritarian, medicalized and oppressive model of health care $e^{24,25}$, emphasizing that promoting the health of the elderly prompts the insertion of these practices quickly, in view of the population profile.

The limitations of this study include the impossibility of the generalization of the results, given the regional delimitation of the research and the specific territory of analysis. However, the singularities highlighted by the different social actors in the reality of the FHS reveal a rich universe of possibilities for understanding the daily demands of this network through the clinical practices of the teams in relation to the social vulnerabilities involving this community space.

\section{CONCLUSION}

Participants reported the occurrence of health promotion actions in a sporadic, unplanned manner, which could result in discontinuous actions of promotion, with a possibility of low impact for this community and territory.

Actions of health promotion, anchored in the practice of health education, should seek to transform reality, with the participants in these experiences acting as co-participants.

A lack of integration can result in dehumanized, fragmented care centered only on the illness and not on the individual and family. Meetings between professionals were emphasized as an important part of the teamwork process, but, ended up not taking place, requiring reflection on the part of the management and teams of the FHS, as PHC workers are responsible for taking part in these actions, using methodologies that allow dialogue and combat the medicalized model which still predominates in work spaces.

Based on this discussion, there is an urgent need to build a health support network for the elderly, shared by professionals, managers and the community, in order to organize services so that health promotion actions can take place in an appropriate manner, allowing elderly persons to receive skilled services at all levels of care to meet their needs.

The present study recommends contributions to the area of health and nursing in view of the need 
to consider the care territory of the FHS, which lacks devices that expose its functioning, question its logic and constitute a symbolic field to reassign practices in daily care. It is therefore possible to construct new health practices, with the perspective of identifying other forms of doing and caring, in the context of the unveiling of daily suffering and confrontation, where clinical care recognizes these limits and conditions of life and breaks with the instituted manner to intervene in the territory of health, strengthening actions of health promotion in the community.

\section{REFERENCES}

1. Schumacher AA, Puttini RF, Nojimoto T. Vulnerabilidade, reconhecimento e saúde da pessoa idosa: autonomia intersubjetiva e justiça social. Saúde Debate [Internet]. 2013 [acesso em 26 nov. 2016];37(97):281-93. Disponível em: http://www. scielo.br/scielo.php?script=sci_arttext\&pid=S010311042013000200010\&lng=pt

2. Miguel EN. O morar contemporâneo do idoso: onde e como reside no estado de Minas Gerais [Dissertação na Internet]. Viçosa: Universidade Federal de Viçosa; 2016 [acesso em 16 jul. 2017]. Disponível em: http:// www.locus.ufv.br/handle/123456789/8179? show=full

3. Brasil. Ministério da Saúde. Envelhecimento e saúde da pessoa idosa [Internet]. Brasília, DF: MS; 2006 [acesso em 26 nov. 2016]. (Cadernos de Atenção Básica, n. 19); (Série A. Normas e Manuais Técnicos). Disponível em: http:/dab.saude.gov.br/portaldab/ biblioteca.php?conteudo=publicacoes $/$ cab19

4. Oliveira TRPR, Mattioli CDP, Barcelos BJ, Horta NC, Lacerda TTB. Promoção da saúde e intersetorialidade na rede de atenção ao idoso. Geriatr Gerontol Aging [Internet]. 2017 [acesso em 16 jul. 2017];11(4):1828. Disponível em: http://docs.bvsalud.org/ biblioref/2017/12/876609/gga-v11n4_pt_182-188.pdf

5. Bontempo APS, Alves AT, Martins GS, Jácomo RH, Malshik DC, Menezes RL. Fatores associados à síndrome da bexiga hiperativa em idosas: um estudo transversal. Rev Bras Geriatr Gerontol [Internet]. 2017 [acesso em 16 jul. 2017];20(4):475-84. Disponível em: http://www.scielo.br/pdf/rbgg/v20n4/19812256-rbgg-20-04-00474.pdf

6. Caldeira RP, Neri AL, Batistoni SST, Cachioni M. Variáveis associadas à satisfação com a vida em cuidadores idosos de parentes também idosos cronicamente doentes e dependentes. Rev Bras Geriatr Gerontol [Internet]. 2017 [acesso em 16 jul. 2017];20(4):503-17. Disponível em: http:// www.scielo.br/pdf/rbgg/v20n4/pt_1981-2256rbgg-20-04-00502.pdf

7. Macinko J, Harris MJ, Phil BS. Brazil's family health strategy: delivering community-based primary care in a Universal Health System. N Engl J Med [Internet]. 2015 [acesso em 23 nov. 2016];372(23):217781. Disponível em: http://www.nejm.org/doi/ pdf/10.1056/NEJMp1501140

8. Rocha DG, Akerman M. Determinação social da saúde e promoção da saúde: isto faz algum sentido para a Estratégia de Saúde da Família? Em que sentido podemos seguir? In: Sousa MF, Franco MS, Mendonça AVM, organizadores. Saúde da Família nos municípios brasileiros: os reflexos dos 20 anos no espelho do futuro. Campinas: Saberes; 2014.

9. Medina MG, Aquino R, Vilasbôas ALQ, Mota E, Pinto Júnior EP, Da Luz LA, et al . Promoção da saúde e prevenção de doenças crônicas: o que fazem as equipes de Saúde da Família? Saúde Debate [Internet] 2014 [acesso em 26 nov. 2016];38(Esp.):69-82. Disponível em: http://www. scielo.br/scielo.php?script $=$ sci_arttext\&pid=S010311042014000600069\&lng=pt

10. Juazeiro do Norte. Secretaria Municipal de Saúde. Relatório Anual de Gestão. Juazeiro do Norte: SMS; 2011.

11. DATASUS [Internet]. Rio de Janeiro: Ministério da Saúde; 1991- . Sistema de Informação da Atenção Básica. Indicadores; 2014 [acesso em 26 nov. 2016]. Disponível em: http://tabnet.datasus.gov.br/cgi/ deftohtm.exe?ibge/cnv/popce.def

12. Bardin L. Análise de Conteúdo. São Paulo: Edições $70 ; 2010$.

13. Tong A, Sainsbury P, Craig J. Consolidated criteria for reporting qualitative research (COREQ): a 32-item check list for interviews and focus groups. Int J Qual Health Care [Internet]. 2007 [acesso em 23 nov. 2016];19(6):349-57. Disponível em: https:// academic.oup.com/intqhc/article/19/6/349/1791966/ Consolidated-criteria-for-reportingqualitative? searchresult $=1$ 
14. Janini JP, Bessler D, De Vargas AB. Educação em saúde e promoção da saúde: impacto na qualidade de vida do idoso. Saúde Debate [Internet]. 2015 [acesso em 26 nov. 2016];39(105):480-90. Disponível em: http://www.scielo.br/scielo.php?script $=$ sci_ arttext\&pid=S0103-11042015000200480\&lng=pt

15. Batista VCL, Ribeiro LCC, Ribeiro CDAL, Paula FA, Araujo A. Avaliação dos atributos da atenção primária à saúde segundo os profissionais de saúde da família. Sanare [Internet]. 2016 [acesso em 26 nov. 2016];15(2):87-93. Disponível em: https://sanare. emnuvens.com.br/sanare/article/view/1042

16. Mendes R, Fernandez JCA, Sacardo DP. Promoção da saúde e participação: abordagens e indagações. Saúde Debate [Internet]. 2016 [acesso em 16 jul. 2016];40(108):190-203. Disponível em: http://www. scielo.br/scielo.php?script $=$ sci_arttext\&pid $=$ S0103 11042016000100190\&lng=pt

17. Silva GGS, Pereira ER, De Oliveira JO, Kodato YM. Um momento dedicado à espera e à promoção da saúde. Psicol Ciênc Prof [Internet]. 2013 [acesso em 23 nov. 2016];33(4):1000-13. Disponível em: http://www. scielo.br/scielo.php?script $=$ sci_arttext\&pid $=$ S1414 98932013000400017\&lng=en\&nrm $=$ iso

18. Cardoso RR, De Brito DM, Soares CMA, Souza SM, De Matos FV, Mendes PHC. Promovendo educação em saúde na sala de espera das unidades de saúde: relato de experiência. Rev Norte Min Enferm [Internet]. 2016 [acesso em 16 jul. 2017];5(1):97-104. Disponível em: http://www.renome.unimontes.br/ index.php/renome/article/view/97

19. Zambenedetti G. Sala de espera como estratégia de educação em saúde no campo da atenção às doenças sexualmente transmissíveis. Saúde Soc [Internet]. 2012 [acesso em 23 nov. 2016];21(4):1075-86. Disponível em: http://www. scielo.br/scielo.php?script=sci_arttext\&pid=S010412902012000400024\&lng=pt. http://dx.doi. org/10.1590/S0104-12902012000400024
20. Castañeda RFG. Proceso caritas en una narrativa de enfermería: cuidando al adulto mayor. Rev Cult Cuid [Internet]. 2015 [acesso em 15 jul. 2017];12(2):79-89. Disponível em: http://repositorio.unilibrepereira. edu.co:8080/Viewer/index.jsp?file=123456789/478/ Art $\% 20 \mathrm{No} \% 207 \% 20$ Caritas.pdf

21. Bomfim ES, Slob EMGB, Oliveira BG, Ribeiro BS, Carmo EA, Santana MLAD, et al. Práticas educativas do enfermeiro no cotidiano na estratégia de saúde da família. Rev Saúde Desenv [Internet]. 2016 [acesso em 16 jul. 2017];10(5):37-52. Disponível em: https://www.uninter.com/revistasaude/index.php/ saudeDesenvolvimento/article/view/512

22. Villa EA, Aranha AVS, Silva LLT, Flôr CR. As relações de poder no trabalho da Estratégia Saúde da Família. Saúde Debate [Internet]. 2015 [acesso em 23 nov. 2016];39(107):1044-52. Disponível em: http://www.scielo.br/scielo.php?script $=$ sci_ arttext\&pid=S0103-11042015000401044\&lng=pt. http://dx.doi.org/10.1590/0103-110420151070365

23. Brasil. Ministério da Saúde. Política Nacional de Atenção Básica [Internet]. Brasília, DF: MS; 2012 [acesso em 23 nov. 2016]. Disponível em: http://189.28.128.100/dab/docs/publicacoes/geral/ pnab.pdf

24. Marques JB, Villela WV. Concepção dos médicos da Atenção Primária de um município do interior do Ceará sobre saúde do idoso. Saúde Debate [Internet]. 2012 [acesso em 23 nov. 2016];36(93):234-42. Disponível em: http://www.redalyc.org/ pdf/4063/406341763011.pdf

25. De Oliveira SRG, Wendhausen ALP. (Re) significando a educação em saúde: dificuldades e possibilidades da Estratégia Saúde da Família. Trab Educ Saúde [Internet]. 2014 [acesso em 26 nov. 2016];12(1):129-47. Disponível em: http://www. scielo.br/scielo.php?script $=$ sci_arttext\&pid $=$ S198177462014000100008\&lng=pt\&nrm=iso 